\title{
Drastic changes in otolith microstructure and microchemistry accompanying the onset of metamorphosis in the Japanese eel Anguilla japonica
}

\author{
Takaomi Arai*, Tsuguo Otake**, Katsumi Tsukamoto \\ Ocean Research Institute, The University of Tokyo, Minamidai, Nakano, Tokyo 164, Japan
}

\begin{abstract}
Otolith microstructure and microchemistry were examined in Anguilla japonica final stage leptocephali and glass eels. Otolith increment width, relatively constant and narrow in the leptocephalus, increased sharply from age 80 to $160 \mathrm{~d}$. Sr:Ca ratios in the otolith, which increased during the leptocephalus stage, thereafter showed a rapid drop, coinciding with the increase in increment width. A comparison of the ontogenic change patterns in otolith increment width and $\mathrm{Sr}$ : Ca ratios between leptocephali and glass eels strongly suggested that these coincidental changes between 80 and $160 \mathrm{~d}$ indicate the onset of metamorphosis in the leptocephali. Metamorphosis appeared to have been completed before the increment width had reached its maximum, suggesting a duration of the former of some 20 to $40 \mathrm{~d}$.
\end{abstract}

KEY WORDS: Eel Anguilla japonica - Metamorphosıs - Otolith Daily growth increments $\cdot$ Sr:Ca ratios

\section{INTRODUCTION}

The spawning area of the Japanese eel Anguilla japonica has been determined as being in the North Equatorial Current west of the Mariana Islands (Tsukamoto 1992). Leptocephali drift from the spawning area toward the coastal waters of eastern Asia via the North Equatorial and Kuroshio Currents. It has been suggested that leptocephali metamorphose to glass eels while they drift along the Kuroshio Current, changing their life style from pelagic to demersal, and that they thereafter begin inshore migration (Tsukamoto \& Otake 1995). Knowledge of the timing and duration of metamorphosis, therefore, seems to be essential for understanding the migration mechanism, geographical distribution and, consequently, lifehistory strategy.

•E-mail: arait@ori.u-tokyo.ac.jp

- Present address: Faculty of Bioresources, Mie University, Kamihama-cho, Tsu 514, Japan
Many reports have shown relationships between otolith characteristics, such as growth pattern (Tabeta et al. 1987, Tsukamoto \& Umezawa 1990, Tzeng 1990 Umezawa \& Tsukamoto 1990, Lecomte-Finiger 1992 Tzeng \& Tsai 1992) and Sr:Ca ratios (Otake et al. 1994, Tzeng \& Tsai 1994, Cheng \& Tzeng 1996, Tzeng 1996), and the timing of metamorphosis in Anguilla spp. However, these relationships have not been validated, and the timing and duration of metamorphosis is still uncertain. This is due to the fact that the above studies have been based only on analysis of glass eels; very few metamorphosing leptocephali (only 4 specimens) having been sampled. Lee \& Byun (1996) and Otake et al. (1997) examined metamorphosing conger eel Conger myriaster leptocephali and defined micro. structual and microchemical fluctuations during metamorphosis.

We collected fully grown Anguilla japonica leptocephali (i.e. just prior to metamorphosis) during the cruise of RV 'Tansei-maru', Ocean Research Institute, The University of Tokyo, conducted in November 
1996. Minute examination of otoliths from these specimens, compared with glass eels, provided important information for determining the relationships between otolith characteristics and metamorphosis. The objectives of this study were to describe the ontogenic changes in otolith microstructure and microchemistry and to determine the relationship between these variations and the timing of metamorphosis in A. japonica.

\section{MATERIALS AND METHODS}

A total of 5 leptocephali and 12 glass eels were used in this study. The leptocephali were collected by oblique tows of $3 \mathrm{~m}$ Isaacs-Kidd Midwater Trawl (IKMT; mesh aperture: $1.0 \mathrm{~mm}$ ) between the surface and $300 \mathrm{~m}$ depth in the North Pacific east of Taiwan, between 20 and 28 November 1996. Water temperature and salinity of the sampling area ranged from 25.9 to $27.5^{\circ} \mathrm{C}$ and from 34.0 to $34.5 \%$, respectively.

The total length of the leptocephali examined ranged from 49.8 to $58.3 \mathrm{~mm}$ (mean $\pm \mathrm{SD}: 54.3 \pm 3.4 \mathrm{~mm}$ ) (Tabie 1), with total myomeres (TM) and preanal myomeres (PAM) ranging from 113 to 116 and 77 to 80 (PAM/TM: 0.68 to 0.70 ), respectively. The anal position, which moves anteriorly during metamorphosis and is used to define each metamorphosis stage (Tanaka et al. 1987), ranged from 75 to 83 in fully grown Anguilla japonica leptocephali (Mochioka 1996). Since the only metamorphosing leptocephali previously collected were 52.0 to $63.0 \mathrm{~mm}$ in TL (Tabeta \& Takai 1975a, b) and a leptocephalus in the early stages of metamorphosis was caught in the sampling net together with the above leptocephali, classification of the latter as fully grown (just prior to metamorphosis) appeared to be justified. Twelve glass eels were collected from the beach of Tanegashima Island, Japan, on 27 December 1996, the total length ranging from 55.7 to $60.7 \mathrm{~mm}$ (mean \pm $\mathrm{SD}: 57.2 \pm 1.5 \mathrm{~mm}$ ). All belonged to the VB stage (metamorphosis recently completed) according to their pigmentation characteristics (Bertin 1956).

Sagittal otoliths extracted from each individual were embedded in epoxy resin (Strues, Epofix) and mounted on glass slides. These samples were then ground to expose the core and further polished with $6 \mu \mathrm{m}$ and $1 \mu \mathrm{m}$ diamond paste on a polishing wheel (Strues, Planopol-V). Subsequently, they were cleaned in an ultrasonic bath, rinsed with deionized water and given a carbon coating by high vacuum evaporation.

Electron microprobe analyses were carried out on all leptocephalus otoliths and those of 5 glass eels (TL range: 55.9 to $59.1 \mathrm{~mm}$, mean $\pm \mathrm{SD}: 57.6 \pm 1.3 \mathrm{~mm}$ ). $\mathrm{Sr}$ and $\mathrm{Ca}$ concentrations (\% dry weight) were measured along the longest axis of the otolith using a wavelength dispersive $\mathrm{X}$-ray electron microprobe (JEOL.
Table 1. Anguilla japonica. Total length (TL), total myomeres (TM), preanal myomeres (PAM), otolith radius and age of leptocephali and glass eels

\begin{tabular}{|c|c|c|c|c|c|}
\hline Specimen & $\begin{array}{c}\mathrm{TL} \\
(\mathrm{mm})\end{array}$ & $T M$ & PAM & $\begin{array}{c}\text { Otolith } \\
\text { radius }(\mu \mathrm{m})\end{array}$ & $\begin{array}{l}\text { Age } \\
\text { (d) }\end{array}$ \\
\hline \multicolumn{6}{|c|}{ Leptocephali } \\
\hline$a^{\bar{a}}$ & 49.8 & 116 & 80 & 82 & 94 \\
\hline$b^{\alpha}$ & 52.1 & 114 & 77 & 96 & 134 \\
\hline$C^{a}$ & 54.8 & 115 & 80 & 93 & 122 \\
\hline$d^{\alpha}$ & 56.4 & 114 & 78 & 101 & 102 \\
\hline$e^{a}$ & 58.3 & 113 & 79 & 94 & 117 \\
\hline \multicolumn{6}{|l|}{ Glass eel } \\
\hline $\mathrm{f}^{\mathrm{a}}$ & 59.1 & & & 151 & 165 \\
\hline$g^{a}$ & 58.8 & & & 159 & 201 \\
\hline $\mathrm{h}^{\alpha}$ & 55.9 & & & 156 & 186 \\
\hline $\mathrm{i}^{\mathrm{a}}$ & 56.8 & & & 149 & 148 \\
\hline$j^{a}$ & 57.5 & & & 149 & 203 \\
\hline $\mathrm{k}$ & 55.7 & & & 151 & 206 \\
\hline 1 & 56.2 & & & 142 & 143 \\
\hline $\mathrm{m}$ & 56.2 & & & 150 & 156 \\
\hline $\mathrm{n}$ & 56.3 & & & 156 & 182 \\
\hline 0 & 56.4 & & & 144 & 181 \\
\hline $\mathrm{p}$ & 57.0 & & & 150 & 170 \\
\hline q & 60.7 & & & 1.5 .3 & 159 \\
\hline
\end{tabular}

JXA-733). Calcite $\left(\mathrm{CaCO}_{3}\right)$ and strontianite $\left(\mathrm{SrCO}_{3}\right)$ were used as standards. Accelerating voltage and beam current were $15 \mathrm{kV}$ and $7 \mathrm{nA}$, respectively. The electron beam was focused on a point about $1 \mu \mathrm{m}$ in diameter, spacing measurements at $1 \mu \mathrm{m}$ intervals. Each data point represents the average of 3 measurements (each counting time: $4.0 \mathrm{~s}$ ). Microprobe measurement points, seen as burn depressions, were assigned to otolith growth increments which were examined as described below. The averages of successive data for $\mathrm{Sr}$ and $\mathrm{Ca}$ concentrations pooled for every 10 successive growth increments were used for the life-history transect analysis.

Following the electron microprobe analysis, the otoliths were repolished to remove the coating, etched with $0.05 \mathrm{M} \mathrm{HCl}$ and vacuum coated with Pt-Pd in an ion-sputterer for observation by scanning electron microscope (SEM, Hitachi S-4500). Otoliths of the remaining 7 glass eels were also etched and prepared for SEM observation in the same way. SEM photographs at magnifications between $1000 \times$ and $2000 \times$ were used for counting growth increments and measuring their widths. The longest axis of the ground otolith surface was regarded as the radius along which increment widths were measured. The averages of every 10 successive increment widths from the hatch check to the edge were used for otolith growth analysis. Since Umezawa et al. (1989), Tsukamoto (1989) and Umezawa \& Tsukamoto (1991) clearly showed that 

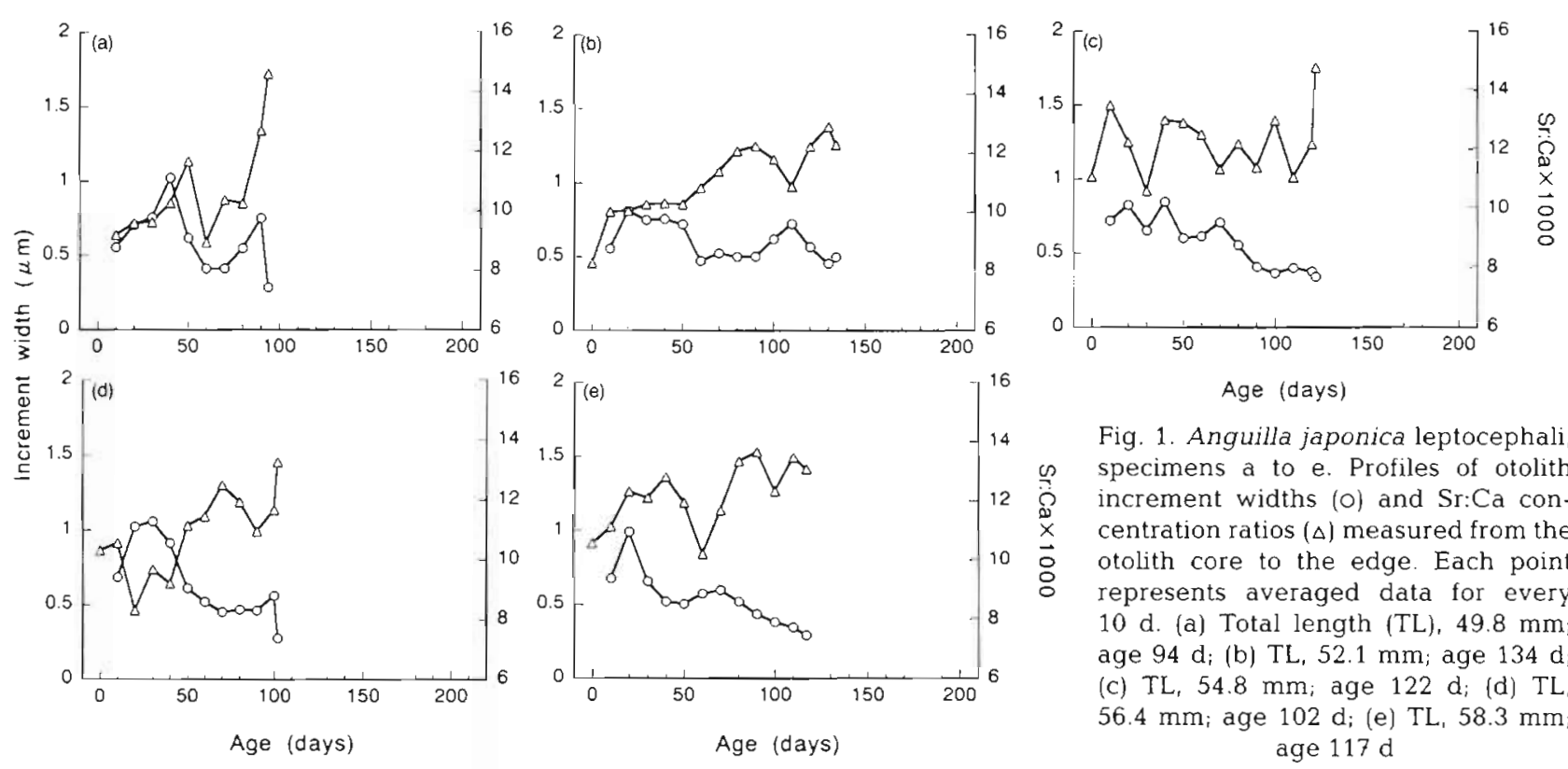

Fig. 1. Anguilla japonica leptocephali specimens a to e. Profiles of otolith increment widths $(0)$ and Sr:Ca concentration ratios $(\Delta)$ measured from the otolith core to the edge. Each point represents averaged data for every $10 \mathrm{~d}$. (a) Total length (TL), $49.8 \mathrm{~mm}$;

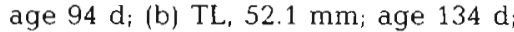
(c) $\mathrm{TL}, 54.8 \mathrm{~mm}$; age $122 \mathrm{~d}$; (d) $\mathrm{TL}$, $56.4 \mathrm{~mm}$; age $102 \mathrm{~d}$; (e) $\mathrm{TL}, 58.3 \mathrm{~mm}$; age $117 \mathrm{~d}$
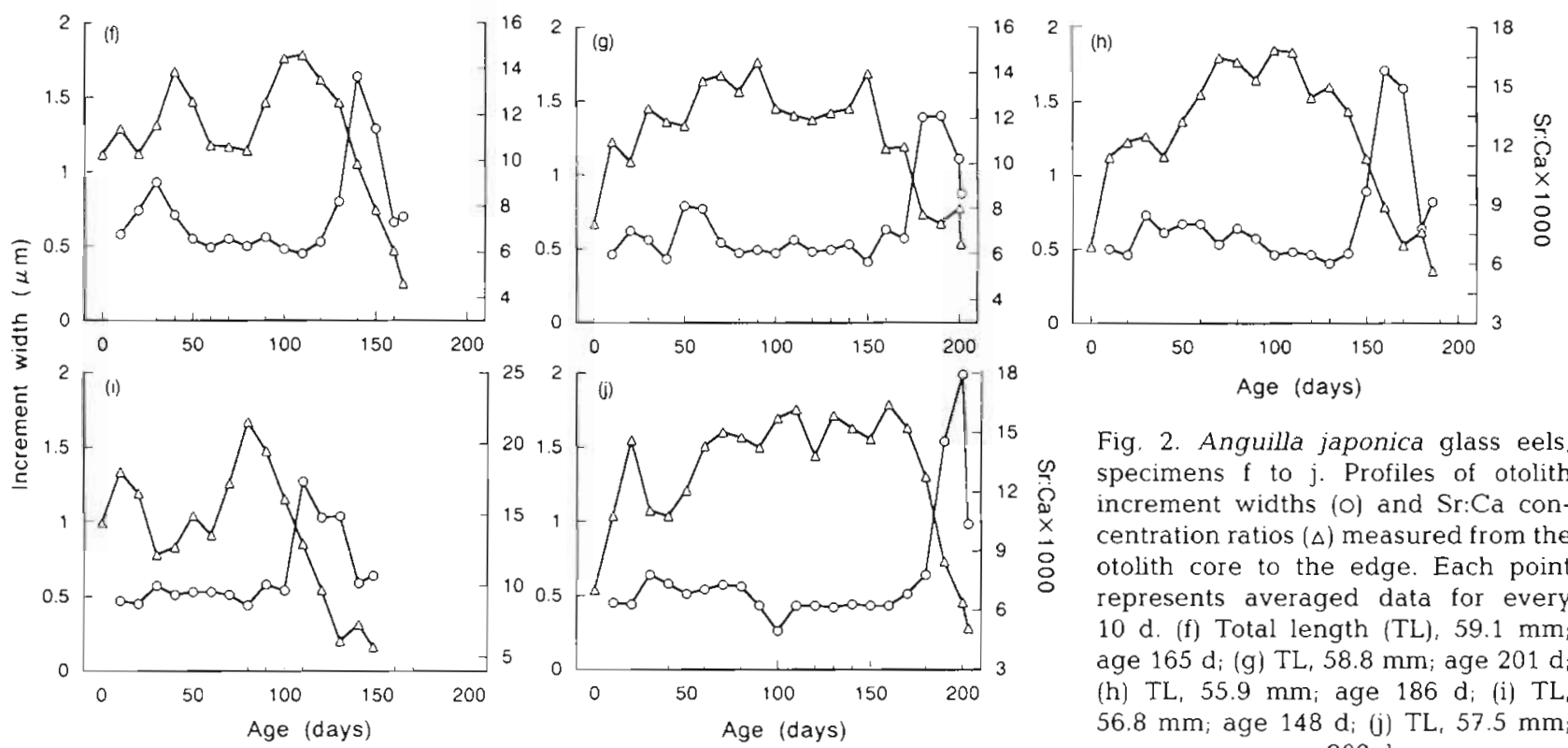

Fig, 2. Anguilla japonica glass eels, specimens $\mathrm{f}$ to $\mathrm{j}$. Profiles of otolith increment widths $(\mathrm{O})$ and $\mathrm{Sr}: \mathrm{Ca}$ concentration ratios $(\Delta)$ measured from the otolith core to the edge. Each point represents averaged data for every $10 \mathrm{~d}$. (f) Total length (TL) $59.1 \mathrm{~mm}$; age $165 \mathrm{~d}_{i}(\mathrm{~g}) \mathrm{TL}, 58.8 \mathrm{~mm}$; age $201 \mathrm{~d}$;

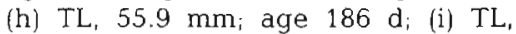

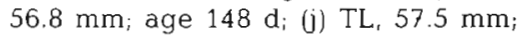
age $203 \mathrm{~d}$

otolith increments in Anguilla japonica were deposited daily, we considered the increment number as directly representing specimen age.

\section{RESULTS}

The ages of 5 fully grown leptocephali and 12 glass eels ranged from 94 to $134 \mathrm{~d}$ and 143 to $206 \mathrm{~d}$, respectively (Table 1). Patterns of change in the otolith increment widths and Sr:Ca ratios in the leptocephali along the life-history transect from the core to the edge are shown in Fig. 1. Otolith increment widths increased between the hatch check and age 20 to $40 \mathrm{~d}$, thereafter becoming constant or gradually decreasing toward the edge. The average increment width was $0.59 \pm 0.19 \mu \mathrm{m}$ (mean $\pm \mathrm{SD}$ ) in the leptocephalus stage. Otolith $\mathrm{Sr}: \mathrm{Ca}$ ratios tended to rise from the core toward the edge. A slight drop in the ratio was found from age 20 to $60 \mathrm{~d}$. The minimum ratio was recorded in the core, and averaged $10.0 \times 10^{-3}$, with the maximum levels, averaging $13.6 \times 10^{-3}$, occurring in the outermost regions.

Fig. 2 shows patterns of change in otolith increment width and $\mathrm{Sr}$ :Ca ratios along the life-history transect of 


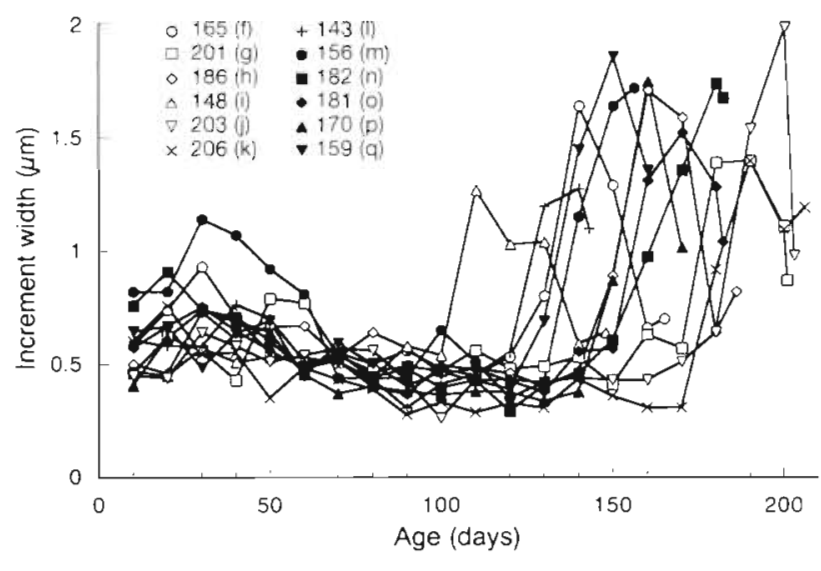

Fig. 3. Anguilla japonica glass eels, specimens f to q. Profiles of otolith incremental width from the otolith core to the edge. Each point represents averaged data for every $10 \mathrm{~d}$

the glass eels. The patterns were characterized by drastic changes in both increment widths and Sr:Ca ratios in the outer region of the otoliths. It was found ind younger specimens, i.e. younger migrants, tended to undergo such drastic changes at an earlier age (Figs. 2 \& 3). Otolith increment width sharply increased during the period 100 to $160 \mathrm{~d}$, followed by a rapid decrease. The duration between the onset of width increase and maximum peak was 20 to $40 \mathrm{~d}$. Sr:Ca ratios reached a maximum level between 80 to $160 \mathrm{~d}$, the marked decrease found thereafter coinciding with the increase in growth increment width. The maximal level of the ratio in glass eels averaged $16.8 \times 10^{-3}$, with the minimum value recorded in the outermost regions of the otoliths, being $5.5 \times 10^{-3}$.

\section{DISCUSSION}

The study showed that the timing of metamorphosis can be defined by a comparison of otolith microstructure and microchemistry between fully grown leptocephali and glass eels. The pattern of change in otolith growth increments in the glass eels was divided into 2 phases, with a shift from the first to the second between 80 and $160 \mathrm{~d}$. The first phase was characterized by a relatively constant or gradually decreasing increment width, which on the whole overlapped with those of the leptocephali. In the second phase, the increment width in glass eels changed dramatically, such a fluctuation not being found in the otoliths of fully grown leptocephali, in which increment widths remained at a low level throughout. Furthermore, Sr:Ca ratios in the otolith showed a drastic decrease in the outer region in glass eel otoliths, whereas the ratio did not drop in the fully grown lep- tocephali. These results suggest that coincidental changes in the otolith increment width and $\mathrm{Sr}: \mathrm{Ca}$ ratios found in glass eel otoliths occurred in the period immediately following the fully grown leptocephalus stage. In the conger eel Conger myriaster, it has been reported that otolith increment widths increased at the beginning of metamorphosis (Lee \& Byun 1996), which coincided with dramatic decreases in otolith Sr:Ca ratios (Otake et al. 1997). Campana (1984) found that otolith growth increment widths widened during the metamorphic period in starry flounder These considerations all lead to the conclusion that a marked increase in otolith increment widths, coinciding with a dramatic decrease in Sr:Ca ratios, heralds the onset of metamorphosis.

Anguilla japonica may complete metamorphosis in the Kuroshio Current (Tsukamoto \& Umezawa 1990) or in marginal waters on the continental shelf (Tabeta \& Takai 1973, Tabeta \& Konishi 1986) before beginning inshore migration. Individual glass eels have been estimated to cover up to $7 \mathrm{~km} \mathrm{~d}^{-1}$ (Umezawa 1991). Since the distance between the flow axis of the Kuroshio Current and the coast of Tanegashima Island (where the glass eels examined here were collected) is $56 \mathrm{~km}$ (Umezawa 1991), direct migration to the coast following metamorphosis in the Kuroshio Current would require some $8 \mathrm{~d}$. Because the minimum number of otolith increments (days) after the maximum peak was only 2 (specimen $\mathrm{n}$ ) and the increment width did not lessen in specimen $m$, it can be confidently suggested that metamorphosis was completed before the age at which the increment widths reach their maximum level. Therefore, the duration of metamorphosis is likely to be at most 20 to $40 \mathrm{~d}$, which agrees with the estimations made by Tabeta et al. (1987), Tsukamoto (1990) and Tzeng \& Tsai (1992).

Changes in otolith $\mathrm{Sr}$ :Ca ratios have been considered related to environmental factors such as water temperature (Radke 1989, Townsend et al. 1989, 1992, 1995. Radke et al. 1990) and salinity (Casselman 1982, Radke et al. 1988, 1996, Kalish 1990, Secor 1992, Secor et al. 1995). In the eel leptocephali, however, the ratios did not seem to be significantly affected by environmental factors. Anguilla japonica leptocephali drift with the North Equatorial Current from the spawning area to the origin of the Kuroshio Current (Kimura et al. 1994). The sampling site of the leptocephali examined was in the transition area between the 2 currents. Because the leptocephali apparently spend their lives in the North Equatorial Current water mass, undergoing only mild variations in environmental conditions, we suggest that the increase in otolith $\mathrm{Sr}$ : Ca ratios during the leptocephalus stage was the result of some endogenous factor(s) rather than environmental factors. As suggested by Otake et al. (1997) for conger eels, variations 
in otolith Sr:Ca ratios in the leptocephali possibly reflected the synthesis and accumulation of body glycosaminoglycan (GAG) during its ontogeny. Furthermore, Otake et al. (1994, 1997) ascertained that drastic changes in otolith Sr:Ca ratios in metamorphosing leptocephali were associated with decreasing body Sr content, caused by catabolism of GAG in the body during metamorphosis. The same phenomenon would probably occur in metamorphosing $A$. japonica leptocephali, as suggested by Otake et al. (1994)

The patterns of change of otolith increment widths and $\mathrm{Sr}$ :Ca ratios along the life-history transect are summarized in Fig. 4, with special reference to the timing of metamorphosis, and oceanic and inshore migration. Although the otoliths of metamorphosing leptocephali could not be examined in this study, future examination of such otoliths should validate the relationships between otolith characteristics and metamorphosis.

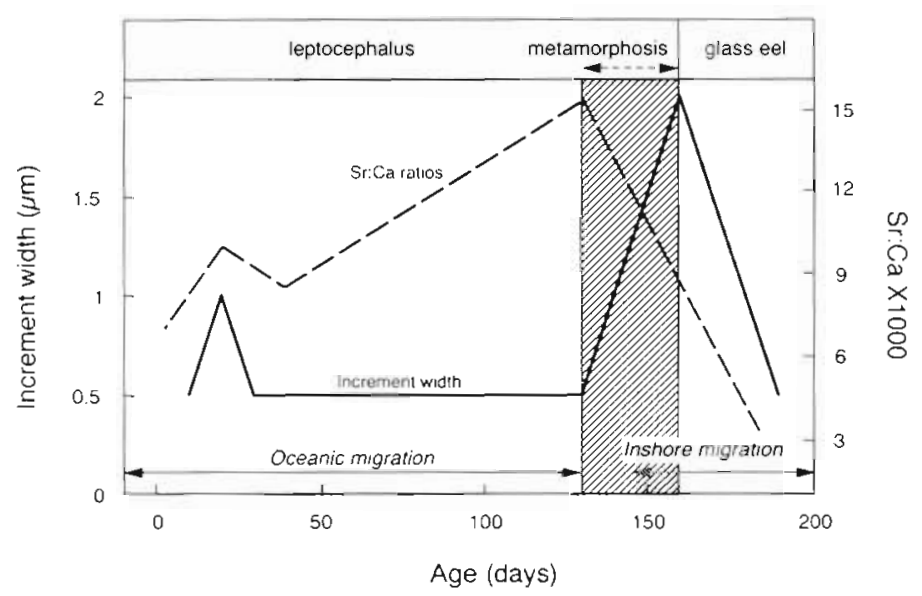

Fig. 4 Anguilla japonica. Patterns of change of otolith increment widths and Sr:Ca ratios in the early life-history of the Japanese eel, with special reference to the timing of metamorphosis and migration Solid and broken lines represent increment widths and Sr:Ca ratios, respectively. The age at onset of metamorphosis represents the average of 12 glass eels examined

Acknowledgements. We are grateful to Dr G. S. Hardy, Thames, New Zealand, for his critical reading of the manuscript, and also thank the crew of RV 'Tansei-maru', Ocean Research Institute, The Unversity of Tokyo, for assistance in sampling. This work was supported in part by Grants-1n-Aid Nos. 07306022,07556046, 08041139 and 08456094 from the Ministry of Education, Science, Sports and Culture, Japan; by Research for the Future Program No. JSPS-RFTF 97L00901 from the Japan Society for the Promotion of Science; and by the Eel Research Foundation from Nobori-kai

\section{LITERATURE CITED}

Bertin L (1956) Eels - a biological study. Cleaver-Hume Press Ltd, London

Campana SE (1984) Microstructual growth patterns in the otoliths of larval and juvenile starry flounder, Platichthys stellatus. Can J Zool 62:1507-1512

Casselman JM (1982) Chemical analyses of the optically different zones in eel otoliths. In: Loftus KH (ed) Proceedings of the 1980 North American Eel Conference. Ontario Fisheries Technical Report No. 4, Ontario, p 74-82

Cheng PW, Tzeng WN (1996) Timing of metamorphosis and estuarine arrival across the dispersal range of the Japanese eel Anguilla japonica. Mar Ecol Prog Ser 131:87-96

Kalish JM (1990) Use of otolith microchemistry to distinguish the progeny of sympatric anadromous and non-anadromous salmonids. Fish Bull US 88:657-666

Kimura S, Tsukamoto K, Sugimoto T (1994) A model for the larval migration of the Japanese eel: roles of the trade winds and salinity front. Mar Biol 119:185-190

Lecomte-Finiger R (1992) Growth history and age at recruitment of European glass eels (Anguilla anguilla) as revealed by otolith microstructure. Mar Biol 114:205-210

Lee TW. Byun JS (1996) Microstructual growth in otoliths conger eel (Conger myriaster) leptocephali during the metamorphic stage. Mar Biol 125:259-268

Mochioka N (1996) Morphology and growth of Japanese eel larvae. In: Tabeta $O$ (ed) Early life-history and prospects of seed production of the Japanese eel Anguilla japonica. Koseisha-Koseikaku, Tokyo, p 22-32

Otake T. Ishii T, Nakahara M. Nakamura R (1994) Drastic changes in otolith strontium/calcium ratios in leptocephali and glass eels of Japanese eel Anguilla Japonica. Mar Ecol Prog Ser 112:189-193

Otake T, Ishii T, Ishii T, Nakahara M. Nakamura R (1997) Changes in otolith strontum:calcium ratios in metamorphosing Conger myriaster leptocephali. Mar Biol 128: $565-572$

Radke RL (1989) Strontium-calcium concentration ratios in fish otoliths as environmental indicators. Comp Biochem Physiol 92(A):189-193

Radke RL, Kinzie RA, Forsom SD (1988) Age at recruitment of Hawaiian fresh watergobies. Environ Biol Fish 23: $205-213$

Radke RL, Svenning M, Malone M, Klementsen A, Ruzicka J, Fey D (1996) Migrations in an extreme northern population of Arctic charr Salvelinus alpinus: insights from otolith microchemistry. Mar Ecol Prog Ser 136:13-23

Radke RL, Townsend DW, Folsom SC, Morrison MA (1990) Strontium:calcium ratios in larval herring otoliths as indicators of environmental histories. Environ Biol Fish 27: $51-61$

Secor DH (1992) Application of otolith microchemistry analysis to investigate anadromy in Chesapeake Bay striped bass Morone saxatilis. Fish Bull US 90:798-806

Secor DH, Henderson-Arzapalo A. Piccoli PM (1995) Can otolith microchemistry chart patterns of migration and habitat utilization in anadromous fishes? J Exp Mar Biol Ecol 192:15-33

Tabeta O, Konishi Y (1986) An anguillid leptocephalus Anguilla japonica from the waters of Miyako lsland, Okinawa, Japan. Bull Jpn Soc Sci Fish 52:1935-1937

Tabeta O, Takai T (1973) An elver of Anguilla japonica found in the northern part of the South China Sea. J Shimono. seki Univ Fish 22(2):49-53

Tabeta O, Takai T (1975a) Leptocephali of Anguilla japonica found in the waters south of the Okinawa Islands. Bull Jpn Soc Sci Fish 41:137-145 
Tabeta O, Takai T (1975b) Leptocephalus of Anguilla japonica found in the waters south of Taiwan. Jpn J Ichthyol 22: $100-103$

Tabeta O, Tanaka K, Yamada J, Tzeng WN (1987) Aspects of the early life history of the Japanese eel Anguilla japonica determined from otolith microstructure. Bull Jpn Soc Sci Fish 53:1727-1734

Tanaka K, Tabeta O, Mochioka N, Yamada J, Kakuda S (1987) Otolith microstructure and ecology of the Conger eel (Conger myriaster) larvae collected in the Seto Inland Sea, Japan. Bull Jpn Soc Sci Fish 53:543-549

Townsend DW, Radke RL, Corwin S, Libby DA (1992) Strontium:calcium ratios in juvenile Atlantic herring Clupea harengus $\mathrm{L}$. otolith as function of water temperature. J Exp Mar Biol Ecol 160:131-140

Townsend DW, Radke RL, Malone DP, Wallinga JP (1995) Use of otolith strontium:calcium ratios for hindcasting larval cod Gadus morhua distributions relative to water masses on Georges Bank. Mar Ecol Prog Ser 119:37-44

Townsend DW, Radke RL, Morrison MA, Folsom SD (1989) Recruitment implications of larval herring overwintering distributions in the Gulf of Maine, inferred using a new otolith technique. Mar Ecol Prog Ser 55:1-13

Tsukamoto K (1989) Otolith daily growth increments in the Japanese eel. Bull Jpn Soc Sci Fish 55:1017-1021

Tsukamoto K (1992) Discovery of the spawning area for the Japanese eel. Nature 356:789-791

Isukamoto K (1990) Recruitment mechanism of the eel, Anguilla japonica, to the Japanese coast. J Fish Biol 36:659-671

Tsukamoto K, Otake T (1995) Japanese eel population and human impact on the resources. In: Soemodihardjo S, Tsukamoto K, Romimohtarto K (eds) Proc 4th LIPI-JSPS

Editorial responsibility: Otto Kinne (Editor),

Oldendorf/Luhe, Germany
Joint Seminar on Mar Sci, 15-18 November 1994. LIPIJSPS, Jakarta

Tsukamoto K. Umezawa A (1990) Early life history and oceanic migration of the eel, Anguilla japonica. La Mer 28:188-198

Tzeng WN (1990) Relationship between growth rate and age at recruitment of Anguilla japonica elvers in a Taiwan estuary as inferred from otolith growth increments. Mar Biol 107:75-81

Tzeng WN (1996) Effects of salinity and ontogenetic movements on strontium:calcium ratios in the otoliths of the Japanese eel, Anguilla japonica Temminck and Schlegel J Exp Mar Biol Ecol 199:111-122

Tzeng WN, Tsai YC (1992) Otolith microstructure and daily age of the Anguilla japonica, Temminck \& Schlegel elvers from the estuaries of Taiwan with reference to unit stock and larval migration. J Fish Biol 40:845-857

Tzeng WN, Tsai YC (1994) Changes in otolith microchemistry of the Japanese eel, Anguilla japonica, during its migration from the ocean to the rivers of Taiwan. J Fish Biol 45 $671-683$

Umezawa A (1991) Early life history and recruitment mechanism of the eel, Anguilla japonica. PhD thesis, The University of Tokyo

Umezawa A. Tsukamoto K (1990) Age and birth date of the glass eel, Anguilla japonica. collected in Taiwan. Bull Jpn Soc Sci Fish 56:1199-1202

Umezawa A. Tsukamoto K (1991) Fartors influencing otolith increment formation in Japanese eel, Anguilla japonica T \& S., elvers. J Fish Biol 39:211- 223

Umezawa A, Tsukamoto K, Tabeta O, Yamakawa H (1989) Daily growth increments in the larval otolith of the Japanese eel, Anguilla japonica. Jpn J Ichthyol 35:440-444

Submitted: August 26, 1997; Accepted: November 17, 1997 Proofs received from author(s): December 22, 1997 